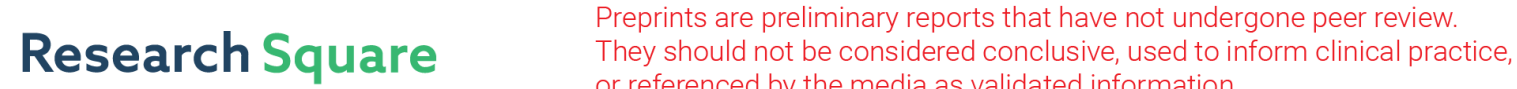 or referenced by the media as validated information. \\ Qualitative and Quantitative Analysis of the Fate of DNA in the Digestive Tract of Mice
}

\section{Xing Ruiqi}

Second Affiliated Hospital of Dalian Medical University

Hui Liu ( $\boldsymbol{\nabla}$ immunology@dmu.edu.cn )

Dalian Medical University

Qi Xia

Dalian Medical University

Pan Lingzi

Dalian Blood Center

\section{Research Article}

Keywords: Mice, Digestive tract, DNA degradation, qPCR and STR

Posted Date: October 1st, 2021

DOI: https://doi.org/10.21203/rs.3.rs-864815/v1

License: (9) This work is licensed under a Creative Commons Attribution 4.0 International License. Read Full License 


\section{Abstract}

Objective: Qualitative and quantitative examination of DNA degradation during the digestion process in the mouse gut through PCR, qPCR and short tandem repeat (STR) analysis.

Methods: Human blood leukocytes were gavage into the digestive tract of mice. GAPDH, TH01, TPOX and D7S820 genes in the contents of the stomach and small intestine were analyzed through PCR and qPCR at various time pre- and post-gavage. Through STR analysis, 21 human genomic DNA loci were analyzed. The half-life of DNA degradation, and the relationship between the average peak area and digestion time were determined.

Results: The PCR results showed DNA bands at pre-gavage (0 min) and post-gavage (40, 80 and 120 min) from the mouse stomach contents, whereas no DNA bands from small intestinal chyme were observed after gavage. The qPCR results revealed significant decrease in DNA concentrations during 40120 minutes in mouse stomach after gavage. At $120 \mathrm{~min}, 85.62 \pm 8.10 \%$ of the DNA was degraded while the half-life of exogenous DNA degradation in mouse stomach was $70.50 \pm 5.46 \mathrm{~min}$. At various time of digestion, almost no target genes were detected in the mouse small intestinal chyme. STR analysis showed a decrease in allele numbers with the advancement of bowl in the small intestine of mice.

Conclusions: The degradation of exogenous DNA was higher in mouse stomach during first two hours while almost complete degradation was noted in the small intestine of mice within 40 min.

\section{Introduction}

Deoxyribonucleic acid digestion and absorption in the gastrointestinal tract (GIT) has been a topic of great interest. Studying the fate of DNA in the digestive tract can be used to assess the risk associated with food and medicine entering the body. Vieira ${ }^{[1]}$ has used PCR to detect human blood DNA in the digestive tract of Aedes aegypti mosquitoes, thus facilitating epidemiological investigation and forensic identification.

Dietary DNA in the digestive tract has been thought to be completely hydrolyzed by digestive enzymes and acids in the mouth and GIT. However, this assumption was made without analysis of the sources or the remaining DNA fragments; instead, it was based on measurement of the biochemical degradation of DNA into single base pairs ${ }^{[2,3]}$. Subsequently, DNA was observed to degrade more rapidly in the upper part of the gastrointestinal tract than in the lower part, and plasmid DNA extracted from the intestinal contents of rats 5 hours after gavage has been found to be biologically active ${ }^{[4]}$. However, Loretz has reported that pig gastric juice and intestinal fluid almost completely degrade plasmid DNA within 1 hour ${ }^{[5]}$. Rabbit DNA has been found in the blood of two volunteers who ate 400-600 grams of cooked rabbit meat ${ }^{[6]}$. DNA fragments have been observed in chicken muscle, liver, spleen and kidney ${ }^{[7-8]}$. Similarly, soybean DNA fragments have been detected in the GIT, tissues and other organs of pigs, sheep and cattle ${ }^{[9-11]}$. However, Walsh ${ }^{[12]}$ has detected cry1 $\mathrm{Ab}$ genes and proteins in the digestive fluids but not 
the tissues (i.e., kidney, liver, muscle, heart or blood) of pigs fed Bt MON810 corn. Sattarzadeh et al. ${ }^{[13]}$ reported the presence of the Nptll gene and Nos promoter sequences in the stomach, but not other tissues, in F-DT and M-LT rats. Trojan reported no detection of purple wheat genes in the blood of chickens, rats and carp fed purple wheat ${ }^{[14]}$. Nawaz et al. ${ }^{[15]}$ found that food DNA can be digested into DNA fragments up to several hundreds of bp, as detected in the GIT. Various researchers have reported similar observations of dietary DNA not only in the GIT in humans or animals, but also in the blood, other tissues or even various organs. The fate of dietary nucleic acids in animals has long been an exciting and controversial research topic.

Digestion of nucleic acids is generally believed to occur in the intestines ${ }^{[16]}$, the main site of digestion and absorption of nutrients and nucleic acids, the latter of which are hydrolyzed by nuclease, phosphodiesterase, alkaline phosphatase and nucleosidase into oligonucleotide-single nucleotide-nonnucleoside bases in the intestine ${ }^{[3,15]}$. Gastric juice consists of pepsin and gastric acid. Pepsin's main function is protein digestion, but in recent years, $\mathrm{Liu}^{[17]}$ found that pepsin in gastric juice can digest not only protein but also nucleic acids. The digestion of nucleic acids starts in the stomach, and various animal pepsins have different abilities to digest nucleic acids ${ }^{[18]}$. Most dietary DNA is in the form of histones, which form nucleosomes. The complex components of the diet may affect the digestion of DNA by pepsin. Zhang ${ }^{[19]}$ has demonstrated that common food components, including proteins, carbohydrates, metal cations and polycationic compounds, affect the digestion of DNA through in vitro simulation studies. Therefore, the digestion of DNA from different sources in animals requires further analysis.

The fate of DNA in the GIT in animals could be used as a model to assess the risk and efficacy of drugs and foods entering the body. The fate of digested DNA and the degradation rates of DNA from various sources in the GIT in different animals have not been studied in detail. Most researchers have studied the degradation of DNA in the GIT of various animals either in extracted animal gastric and intestinal fluids or through in vitro simulation models. In in vitro studies, many factors must be controlled, such as temperature, $\mathrm{pH}$, ionic strength, enzyme concentration, GIT flora and epithelium. Mice have been used as a model to explore the dietary DNA degradation and digestion process in the mouse GIT at various time intervals. The DNA degradation rate has been quantitatively analyzed.

At present, study of dietary DNA traceability has been mainly based on the polymerase chain reaction (PCR) technique. The minimum amplifiable fragment length is $70-100 \mathrm{bp}^{[20-21]}$. Gene degradation into fragments below $70 \mathrm{bp}$ remains to be further studied.

Short tandem repeat (STR) sequences are a series of small DNA fragments of 2-7 bp repeating approximately 10-60 times in the human genome. STR loci are highly polymorphic and widely distributed. The allelic fragment range is small, and multiple detections of multiple loci can be performed. Allele loss caused by small fragment dominant amplification can also be reduced through STR analysis. 
The target fragment after PCR amplified is small; therefore, STR analysis is suitable for the detection of degraded DNA ${ }^{[22]}$.

This study human blood genomic DNA was chosen as an exogenous gene to infused into the digestive tract in mice and used PCR, qPCR and STR automatic analysis to qualitatively and quantitatively analyze the degradation of genes in human genomic DNA into small fragments in the digestive tract in mice over time, and to calculate the DNA degradation rate and half-life.

\section{Materials And Methods}

2.1 We confirm that all methods were carried out in accordance with ARRIVE guidelines and regulations in manuscript, and all experimental protocols were approved by the University Ethics Committee of Dalian Medical University, the ethics number is: AEE18036.

\subsection{Experimental animals.}

Kunming mice were obtained from the Experimental Animal Center of Dalian Medical University. The mice weighed approximately $17-30 \mathrm{~g}$, and both sexes were included.

\subsection{Observation and calculation of the small bowel advancement rate.}

\subsubsection{Preparation of nutritive semi-solid paste.}

Previously described methods were followed ${ }^{[23]}$ with slight modifications. A total of $5 \mathrm{~g}$ sodium carboxymethylcellulose was dissolved in $125 \mathrm{~mL}$ distilled water. Then the following were added: $8 \mathrm{~g}$ milk powder, $4 \mathrm{~g}$ sugar, $4 \mathrm{~g}$ starch and $2 \mathrm{~g}$ activated carbon. The mixture was stirred gently, and $150 \mathrm{ml}$ containing approximately $150 \mathrm{~g}$ of a black semisolid paste was prepared. The product was stored at $4^{\circ} \mathrm{C}$ and was brought to room temperature before gavage.

\subsubsection{Gavage in mice.}

After fasting for 24 hours, the mice were gavage with a nutritional semi-solid paste $(0.8 \mathrm{ml})$ and water.

\subsubsection{Mouse sacrifice and dissection.}

Three mice per group were sacrificed by cervical dislocation at the following time intervals: $10,20,30,40$, $50,60,70,80,90,120,150,180,360,420,510,540$ or $570 \mathrm{~min}$. Through incision of the abdominal cavity, the stomach and intestine were separated. The small intestine was measured from the pylorus to the ileocecal region (d1). The distance from the pylorus to the mid-point of the black semi-solid paste was measured (d2). The small bowel advancement rate was calculated as: 
$\frac{\mathrm{d} 2}{\mathrm{~d} 1} \times 100 \%$

\subsection{Qualitative analysis of target genes by PCR. \\ 2.4.1 Preparation of the buffy coat layer.}

A total of $35 \mathrm{ml}$ of human EDAT whole blood was obtained from a healthy volunteer donor at Dalian Medical University and informed consent was obtained from her. Blood samples were centrifuged at 5000 $\mathrm{g}$ for $10 \mathrm{~min}$. Plasma was discarded, and the buffy coat layer was carefully collected and stored at $4^{\circ} \mathrm{C}$.

\subsubsection{Screening of exogenous target genes.}

In this experiment, human blood genomic DNA was used for exogenous target gene screening. The nonhomologous human housekeeping gene GAPDH (F:5'-AGTGGAAGACAGAATGG AAGAAATG-3'; R:5'TGGGGACAGGACCATATTGAG-3') And TH01 [24] (F:5'-ATTCAAA GGGTATCTGGGCTCTGG-3'; R:5'GTGGGCTGAAAAGCTCCCGATTAT-3'), TPOX (F:5'-TGCGTAATCCTCCACTAACTGA-3'; R:5'TCCAACGGGAATGGCTCT-3') and D7S820 (F: 5'-CACCTGTTACCTCCAGTTTCC-3'; R: 5'TTTGCTGCTTTAGTCTTCC TTC-3') were obtained from Dalian Ruizhen Biotechnology and Suzhou Gema Gene as the target genes respectively. PCR primers for GAPDH, TH01, TPOX and D7S820 were used to amplify human and mouse DNA according to the instructions of the E.Z.N.A. blood DNA kit (Beijing Solarbio). The amplification reaction was performed in $25 \mu$ l volumes containing $2 \mu l$ template DNA, $0.5 \mu l$ each of forward and reverse primers, $12.5 \mu$ of $2 \times$ Power Taq PCR Master Mix and $9.5 \mu l$ of deionized water. Thermal cycling was conducted under the following conditions: initial denaturation step $\left(94^{\circ} \mathrm{C} ; 60\right.$ s), denaturation $\left(94^{\circ} \mathrm{C} ; 30 \mathrm{~s}\right)$, annealing $\left(51^{\circ} \mathrm{C} ; 30 \mathrm{~s}\right)$ and extension $\left(72^{\circ} \mathrm{C} ; 30 \mathrm{~s}\right)$, for a total of $35 \mathrm{cycles}$. The results of the agarose gel electrophoresis were analyzed with a UVPC-80 gel imaging system (UCP Inc., San Jose, CA, USA).

\subsubsection{Gavage and DNA extraction.}

Nutritive semi-solid paste was prepared as described above, except with the addition of $2 \mathrm{~g}$ of activated carbon powder. A total of $0.4 \mathrm{ml}$ semi-solid nutrient paste was mixed with the buffy coat $(0.4 \mathrm{ml})$. The nutrient semi-solid paste was administered to mice by gavage. Mice were sacrificed by cervical dislocation at time intervals of $0,40,80$, or $120 \mathrm{~min}$. Through incision of the abdomen, an equal amount of stomach and small intestine content was collected in a $1.5 \mathrm{ml}$ EP tube. DNA was extracted according to the kit instructions and analyzed through PCR. The results of agarose gel electrophoresis were analyzed with a UVPC-80 gel imaging system.

\section{5 qPCR determination of the kinetics of DNA degradation in the digestive tract in mice.}

The extracted DNA samples were amplified. The amplification reactions were performed in $20 \mu \mathrm{l}$ volumes containing $2 \mu \mathrm{l}$ of template DNA, $0.4 \mu \mathrm{l}$ each of forward and reverse primers, $10 \mu \mathrm{l}$ of $2 \times$ ChamQ Universal

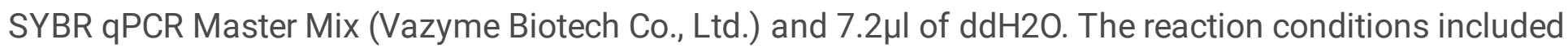


pre-denaturation $\left(95^{\circ} \mathrm{C}, 30 \mathrm{~s}\right)$, denaturation $\left(95^{\circ} \mathrm{C}, 5 \mathrm{~s}\right)$ and annealing $\left(60^{\circ} \mathrm{C}, 45 \mathrm{~s}\right)$; after 40 cycles of amplification, the results of the reaction were detected with a qPCR instrument MA-6000 (Molarray, Suzhou, China) and analyzed.

\subsection{STR determination of the kinetics of DNA degradation in the digestive tract in mice.}

The extracted DNA was analyzed through STR typing detection with a AGCU Expressmarker 22 Fluorescence Detection Kit (Wuxi Zhongde Meilian Biotechnology Co., Ltd.). Twenty-one STR loci were amplified; D19S433, D5S818, D21S11, D18S51, D6S1043, D3S1358, D13S317, D7S820, D16S539, CSF1PO, PentaD, D2S441, VWA, D8S1179, TPOX, PentaE, TH01, D12S391, D2S1338, FGA and AMEL. According to the instructions, each PCR amplification was performed in a $10 \mu$ reaction. The amplification conditions were pre-denaturation $\left(95^{\circ} \mathrm{C}, 2 \mathrm{~min}\right)$, denaturation $\left(94^{\circ} \mathrm{C}, 30 \mathrm{~s}\right)$, annealing $\left(60^{\circ} \mathrm{C}\right.$, $1 \mathrm{~min})$ and extension $\left(70^{\circ} \mathrm{C}, 1 \mathrm{~min}\right)$, for 10 cycles of amplification; then denaturation $\left(90^{\circ} \mathrm{C}, 30 \mathrm{~s}\right)$, annealing $\left(58^{\circ} \mathrm{C}, 1 \mathrm{~min}\right)$ and extension $\left(72^{\circ} \mathrm{C}, 1 \mathrm{~min}\right)$, for 20 cycles of amplification and extension for 10 min at $72^{\circ} \mathrm{C}$. After amplification, $1 \mu \mathrm{l}$ of PCR product was loaded onto an ABI 3130 Avant Genetic Analyzer (Forster, California Applied Biosystems) for capillary electrophoresis, and GeneMapper@ID software v3.2 (Applied Biosystems, Foster City, California) was used to analyze the data. Allele peaks were labeled when the peak area was $\geq 50$ relative fluorescence units (RFU). The relative concentration of DNA degradation was calculated according to the STR spectrum and peak area generated by the software.

\subsection{Data analysis.}

\subsubsection{Relative quantification of DNA through qPCR method:}

According to the qPCR amplification principle, the PCR product increases exponentially. Assuming that the amplification efficiency was " $\mathrm{E}$ ", and the initial quantity of template was "NO", then the amount of PCR product after " $m$ " cycles was "Nm". Hence, according to formula; $\mathrm{Nm}=\mathrm{n}_{0}(1+\mathrm{E})^{\mathrm{m}}$. The initial quantity of template at 0 minutes of gavage was recorded as "NO", after "Ct0" cycles, and reached the baseline "Nq" while the initial quantity of template at different times of gavage was recorded as "Nn", at "Ctn" cycles, and reached the baseline "Nq". Therefore, $\mathrm{NO}(1+\mathrm{E})^{\mathrm{Ct0}}=\mathrm{Nn}(1+\mathrm{E})^{\mathrm{Ctn}}$. So, assumed that the

$$
\text { amplification Efficiency was 1. Then, according to the formula } \frac{N n}{N 0}=2^{(\mathrm{Ct} 0-\mathrm{Ctn})},
$$
the relative quantity of DNA in stomach of mice at different digestion times was calculated.

\subsubsection{STR result analysis}

The relative concentrations of degraded DNA, expressed as the mean peak area, was calculated by dividing the sum of the interpreted peak areas by the total peak number of the full STR profile (Table 1). STR patterns (Figure 1) amplified from gastric content DNA, 0 min after gastric gavage were shown as an example to illustrate the calculation method of the average peak area. 
Table 1

Post gavage ( $0 \mathrm{~min})$ STR analysis: loci, alleles and peak areas

\begin{tabular}{|c|c|c|c|c|c|c|c|c|c|}
\hline \multirow{2}{*}{$\begin{array}{l}\text { Locus } \\
\text { D19S433 }\end{array}$} & \multicolumn{2}{|c|}{ Allele } & \multicolumn{2}{|c|}{ Peak area } & \multirow{2}{*}{$\begin{array}{l}\text { Locus } \\
\text { Penta D* }\end{array}$} & \multicolumn{2}{|c|}{ Allele } & \multicolumn{2}{|c|}{ Peak area } \\
\hline & 13 & 14 & 51595 & 44400 & & 9 & - & 67023 & - \\
\hline D5S818 & 11 & 13 & 45242 & 40189 & D2S441 & 10 & 11 & 71981 & 59984 \\
\hline D21S11 & 30 & 32.2 & 39591 & 43919 & vWA & 15 & 16 & 82882 & 78403 \\
\hline D18S51 & 13 & 19 & 37318 & 29596 & D8S1179* & 15 & - & 110223 & - \\
\hline D6S1043 & 18 & 19 & 34582 & 31183 & TPOX & 8 & 12 & 116575 & 104151 \\
\hline AMEL* & $x$ & - & 65353 & - & Penta E & 11 & 17 & 106722 & 84672 \\
\hline D3S1358 & 16 & 18 & 28865 & 27571 & TH01 & 6 & 7 & 101214 & 94798 \\
\hline D13S317 & 8 & 12 & 46242 & 36760 & D12S391 & 19 & 24 & 52279 & 46793 \\
\hline D7S820* & 11 & - & 88244 & - & D2S1338 & 23 & 25 & 113265 & 48908 \\
\hline D16S539 & 10 & 13 & 48549 & 51712 & FGA & 21 & 22 & 64963 & 57056 \\
\hline CSF1PO & 10 & 12 & 45441 & 41806 & - & - & - & - & - \\
\hline \multicolumn{10}{|c|}{ *Represents homozygote } \\
\hline Average & & $=(51$ & - & - & & & & & 158 \\
\hline
\end{tabular}

Linear regression analysis was performed. The slope $(K)$ was calculated between the natural logarithm (In) of the average peak area and the digestion time. The half-life of DNA degradation in the mice stomach was determined using the following formula ${ }^{[25]}$.

$T^{1} / 2=\ln 2 /|k|$

\section{Results}

\subsection{Advancement rate of nutritional semi-solid paste in the GIT in mice.}

Figure 2 and Figure 3 show the positions of the nutritive semi-solid paste in the GIT in mice at various times after gavage (black indicates the position of the nutrient semi-solid paste). The semi-solid paste in the stomach and intestine in mice was observed, and the intestinal advancement rate was measured (Table 2). At 10 min after gavage, the intestinal advancement rate was $20.27 \pm 2.60 \%$, and the small intestine advancement appeared segmented after $20 \mathrm{~min}$. The mouse stomach was completely emptied in approximately $360 \mathrm{~min}$. The stomach and small intestine were completely emptied in approximately $540 \mathrm{~min}$, and all the semi-solid paste entered the cecum. 
Table 2

Digestion time, length of small intestine and small bowel advancement rate of nutrient semi-solid paste in the GIT in mice.

\begin{tabular}{|c|c|c|c|c|c|c|}
\hline \multirow{2}{*}{$\begin{array}{l}\text { Digestion } \\
\text { time(min) }\end{array}$} & \multirow{2}{*}{$\begin{array}{l}\text { Length of } \\
\text { small } \\
\text { intestine(cm) }\end{array}$} & \multicolumn{4}{|c|}{ Small bowel advancement rate (\%) } & \multirow{2}{*}{$\begin{array}{l}\text { Surplus } \\
\text { in } \\
\text { stomach }\end{array}$} \\
\hline & & First stage & $\begin{array}{l}\text { Second } \\
\text { stage }\end{array}$ & Third stage & $\begin{array}{l}\text { Fourth } \\
\text { stage }\end{array}$ & \\
\hline 10 & $34.75 \pm 1.48$ & $20.27 \pm 2.60$ & - & - & - & + \\
\hline 20 & $32.27 \pm 7.18$ & $9.70 \pm 6.43$ & $31.86 \pm 9.76$ & - & - & + \\
\hline 30 & $35.83 \pm 4.80$ & $11.77 \pm 8.11$ & $44.05 \pm 16.66$ & - & - & + \\
\hline 40 & $38.90 \pm 1.98$ & $15.93 \pm 5.55$ & $47.77 \pm 12.11$ & - & - & + \\
\hline 50 & $37.10 \pm 1.41$ & $18.74 \pm 6.91$ & $56.01 \pm 16.93$ & - & - & + \\
\hline 60 & $36.45 \pm 2.76$ & $48.47 \pm 3.18$ & $89.59 \pm 7.56$ & - & - & + \\
\hline 70 & $41.6 \pm 5.60$ & $38.76 \pm 5.11$ & $59.20 \pm 8.8$ & $88.20 \pm 8.45$ & - & + \\
\hline 80 & $40.85 \pm 4.88$ & $47.53 \pm 3.50$ & 72.33 & $88.70 \pm 5.40$ & - & + \\
\hline 90 & $45.10 \pm 2.40$ & $31.68 \pm 5.22$ & $63.44 \pm 5.11$ & $89.51 \pm 5.55$ & - & + \\
\hline 120 & $45.70 \pm 1.70$ & - & - & $79.09 \pm 0.78$ & 100 & + \\
\hline 150 & $52.95 \pm 1.91$ & $30.18 \pm 12.93$ & $72.37 \pm 11.21$ & $97.10 \pm 4.11$ & 100 & + \\
\hline 180 & $57.25 \pm 4.45$ & $44.59 \pm 6.72$ & $65.58 \pm 7.00$ & $85.83 \pm 8.58$ & $98.99 \pm 1.44$ & + \\
\hline 360 & $36.25 \pm 2.75$ & - & 56.12 & 87.61 & 100 & - \\
\hline 420 & $36.03 \pm 2.66$ & - & - & $81.44 \pm 10.42$ & 100 & - \\
\hline 510 & $45.45 \pm 3.18$ & - & - & $67.18 \pm 2.69$ & 100 & - \\
\hline 540 & $43.55 \pm 5.30$ & - & - & - & 100 & - \\
\hline 570 & $38.4 \pm 0.57$ & - & - & - & 100 & - \\
\hline
\end{tabular}

\subsection{PCR results of exogenous DNA target genes.}

The selected exogenous target genes GAPDH, TH01, TPOX and D7S820 were analyzed for homologous sequences. DNA bands were detected for human target genes, whereas no bands were detected for mouse genes(Figure 4).

\subsection{PCR results of DNA degradation in the mouse GIT.}

The results of PCR in Figure 5 revealed the target DNA bands for GAPDH, D7S820 (i.e., lanes A1, A2, B1, $\mathrm{C} 1$, and $\mathrm{D} 1)$ in the stomach contents at various times (0-120 min) pre and post gavage. No DNA bands 
were observed in the small intestine contents (i.e., lanes B2, B3, C2, C3, D2 and D3) at 40-120 min after gavage, as shown in Figure 5. The TH01 and TPOX gene amplification results (Figure 6) showed the presence of the target DNA bands in lanes $A 1$ and $A 2$ (0 min; pre-gavage); lanes B1, C1, and D1 represent the stomach contents and showed clear bands at 40,80 and 120 min post-gavage, respectively. No DNA bands (TH01 and TPOX) were observed in the chyme obtained after 40-120 min from the small intestine (i.e., lanes B2, B3, C2, C3, D2 and D3) at various times after gavage, as shown in Figure 6.

\section{4 qPCR results of DNA degradation in the mouse GIT.}

The GIT contents were also analyzed through qPCR for the target genes (i.e., GAPDH, TH01, TPOX and D7S820) pre-gavage ( $0 \mathrm{~min}$ ) and at different times post-gavage (i.e., 40, 80 and $120 \mathrm{~min}$ ). The four target genes were amplified, and each group was analyzed three times. Pre and post-gavage times and the $\mathrm{Ct}$ values of four target genes were plotted in Figure 7.

The relative quantification of the four targeted genes at different digestion time was calculated, as shown in Table 3 and Figure 8. Significant decrease in DNA relative concentration was observed at 40,80, and 120 min respectively, of post-gavage as compare with pre-gavage (Table 3 ). At 120 min $85.62 \pm 8.10 \%$ decrease in concentration was noted as compared with 0 min of gavage. According to the linear analysis, the digestion time and exogenous DNA degradation in mouse stomach was shown in Figure 9. The halflife of DNA degradation in mouse stomach was $70.50 \pm 5.46$ minutes.

Table 3

Relative Ct values of DNA for four target genes in mice stomach at different digestion time.

\begin{tabular}{|lllll|}
\hline Time & GAPDH & TH01 & TPOX & D7S820 \\
\hline Omin & 1.0000 & 1.0000 & 1.0000 & 1.0000 \\
\hline $40 \mathrm{~min}$ & 0.6152 & 0.7043 & 0.5972 & 0.3271 \\
\hline $80 \mathrm{~min}$ & 0.5888 & 0.5647 & 0.6784 & 0.4175 \\
\hline $120 \mathrm{~min}$ & 0.1563 & 0.1169 & 0.1846 & 0.1174 \\
\hline
\end{tabular}

qPCR was used to detect the DNA amplification curve (Figure 10), and the Ct values of the contents of different areas of the mouse GIT (stomach, upper small intestine and lower small intestine) at 40 min after gavage are shown in Table 4. From the amplification curve, the $\mathrm{Ct}$ value of the mouse gastric contents at $40 \mathrm{~min}$ was approximately $26(<35)$. The $\mathrm{Ct}$ values of the four target genes in the upper part of the small intestine of the mice at 40 min were all less than 35; in the lower part of the small intestine of the mice at 40 min, only the GAPDH gene had a Ct value less than 35, and the Ct value of the other three target genes was greater than 35 . Similarly, the target genes were not detected in the DNA of the small intestine contents in mice at the other times after gavage (Figure 10). 
Table 4

Ct values of the four target genes from various region of digestive tract's content of mice at 40 min after gavage.

\begin{tabular}{|llll|}
\hline $\begin{array}{l}\text { Target } \\
\text { gene }\end{array}$ & \multicolumn{2}{l|}{ Threshold Cycle (Ct) } \\
\cline { 2 - 4 } & $\begin{array}{l}\text { Gastric content } \\
\text { DNA }\end{array}$ & $\begin{array}{l}\text { Small intestine Chyme DNA } \\
\text { (Upper part) }\end{array}$ & $\begin{array}{l}\text { Small intestine Chyme DNA } \\
\text { (lower part) }\end{array}$ \\
\hline GAPDH & 26.78 & 34.88 & 34.7 \\
\hline TH01 & 27.96 & 34.785 & 35.53 \\
\hline TPOX & 26.16 & 33.65 & 35.285 \\
\hline D7S820 & 26.4 & 33.785 & 36.535 \\
\hline
\end{tabular}

\subsection{STR results of DNA degradation in the mouse GIT.}

The STR patterns of the DNA samples obtained from the mouse stomach at 0 min post-gavage are shown in Figure 1. We used the average peak area as the concentrations of degraded DNA at different digestion times in the mouse stomach, as shown in Figure 11A. The concentration of DNA decreased after digestion in the stomach in mice at $0 \mathrm{~min}$. The concentration of DNA did not change significantly during 40-80 min and remained stable. After $120 \mathrm{~min}$, the DNA concentration decreased significantly.

A linear regression was calculated with the natural logarithm of the average peak area versus digestion time, as shown in Figure 11B. The degradation kinetic model was obtained. According to the formula: $\mathrm{T}^{1} 1 / 2=$, the half-life of DNA degradation in the mouse stomach was $63.13 \mathrm{~min}$.

Through STR, the average peak area and the total number of alleles amplified were measured in various parts of the mouse digestive tract, and were 38, 4 and 1, in the stomach, upper small intestine and lower small intestine, respectively, at 40 min post gavage (Table 5). The results after 40 min were comparable, and over time, fewer alleles were amplified. The STR average peak area in different parts of the GIT decreased significantly with the advancement of bowel/chyme, as indicated by the decrease in the number of alleles detected in the stomach, upper and lower small intestine in mice.

Table 5

The average peak area and the number of alleles in the STR curve map of the DNA amplification of the contents of different parts of the mouse digestive tract 40 min after gavage.

\begin{tabular}{|lll|}
\hline Samples & Average peak area(RFU) & Total alleles \\
\hline Stomach contents DNA & 24010.42 & 38 \\
\hline DNA of upper small intestine & 521.08 & 4 \\
\hline DNA of lower intestine contents & 176.58 & 1 \\
\hline
\end{tabular}

\section{Discussion}


Food and medicine are vital to human survival. Hybrid food products are produced to feed humans and livestock. Recently nucleic acid treatment through parenteral or GIT administration has been reported ${ }^{[26]}$. The nucleic acid fate in the GIT tract has been unclear. A mouse model was developed to study the fate of DNA in the digestive tract in mice.

The advancement rate was found to be $20.27 \pm 2.60 \%$ at $10 \mathrm{~min}$ post gavage. The advancement in the movement of bowel/chyme was observed in the GIT in mice. At 180 to $360 \mathrm{~min}$ post-gavage, the mouse stomach was completely emptied, and the contents of the stomach had fully entered the small intestine. This finding is consistent to those reported by Chul-Hyun Lim ${ }^{[27]}$, who used a ${ }^{13} \mathrm{C}$ octanoic acid breath test to measure gastric emptying times in mice. After 510 to $570 \mathrm{~min}$ of digestion, all contents had entered the cecum. This would provide understanding of the advancement of bowel movement.

Currently, the most commonly used DNA-based detection techniques are PCR and qPCR. qPCR, the most commonly used DNA quantification method, has the advantages of low pollution and high specificity ${ }^{[28]}$. As shown in Figures 5 and 6 , clear bands in the mouse stomach were observed pre-gavage ( $0 \mathrm{~min})$ and post-gavage (i.e., during 40-120 min). These results confirmed the presence of human leukocyte DNA in the stomach in mice after $120 \mathrm{~min}$ of digestion (>200 bp). There were no observed DNA bands for the four target genes in the contents of the small intestine in mice at 40,80 and $120 \mathrm{~min}$ after gavage. The DNA had degraded into fragments of $<77$ bp in the small intestine in mice. Nawaz ${ }^{[15]}$ found that food DNA can survive in the digestion process, and DNA fragments up to several hundred bp can be detected in the GIT. Same as the results of other scholars ${ }^{[9-13]}$, DNA fragments can clearly be detected in the GIT of animals; however, whether they can be detected in the blood and other tissues requires further experiments.

Anatomically, the mouse stomach consists of two regions-the non-glandular/fore-stomach and glandular stomach-which are separated by a limiting ridge ${ }^{[29]}$. Gastric juice consists of pepsin and gastric acid. Pepsin's main function is to digest protein, but in recent years, $\mathrm{Liu}^{[17]}$ found that the pepsin in gastric juice can digest not only protein but also nucleic acid. The digestion of nucleic acid starts in the stomach, and various animal pepsins have different abilities to digest nucleic acid ${ }^{[18]}$. Most dietary DNA is in the form of histones, which form nucleosomes. The complex components of the diet may affect the digestion of DNA by pepsin. Zhang ${ }^{[19]}$ demonstrated that common food components, including proteins, carbohydrates, metal cations and polycationic compounds, are closely associated with the digestion of DNA through in vitro simulation studies.

Ct values in the gastric contents of mice at $0,40,80$ and 120 min respectively after gavage were measured through qPCR as shown in Figure 7. The DNA concentration decreased consistently from 0 to $120 \mathrm{~min}$ post gavage, and at $120 \mathrm{~min}, 85.62 \pm 8.10 \%$ decrease was noted as compared with 0 min (Table 3). The half-life of DNA degradation in mouse stomach was 70.50 $\pm 5.46 \mathrm{~min}$ (Figure 9). This indicated that the DNA concentration in the mice stomach decreased significantly. Wiedemann $S{ }^{[30]}$ analyze rubisco and cry $1 \mathrm{Ab}$ gene through real-time PCR and reported that the degradation was $20 \%$ of the initial 
value at 2 hours as compare with 0 hour. The degradation was $0.5 \%$ of the initial value ( 0 hour) after incubated for 48 hours in the rumen.

DNA degradation may be associated with mechanical aspects, gastric juice and microorganisms in the mice stomach. The DNA was not completely degraded in the stomach of mice, and remained $>200 \mathrm{bp}$ of DNA fragments. Protein and carbohydrate, the main components of food, do not affect DNA digestion at the concentrations recommended by the WHO (40:1 and 80:1). When the ratio of protein to DNA is $>80: 1$, DNA digestion is inhibited ${ }^{[18]}$. Divalent cations $\left(\mathrm{Ca}^{+}\right.$and $\left.\mathrm{Mg}^{2+}\right)$ can result in greater DNA digestion than monovalent cations $\left(\mathrm{Na}^{+} \text {and } \mathrm{K}^{+}\right)^{[18]}$. The gavage included nutritive semi-solid paste and human white blood cells. The sodium carboxymethyl cellulose, starch and milk powder in the nutritive semi-solid paste resembled normal dietary components, thus potentially inhibiting DNA digestion. In addition, the structure of human leukocytes includes a cell membrane and nucleus, which may protect against DNA digestion. According to Zhang, pepsin has a digestive effect toward nucleic acid, on the basis of in vitro simulation: pepsin can digest specific sequences nucleic acids, such as $5^{\prime}-A A G \downarrow A A-3^{\prime}$ and CGA $\downarrow T^{[17]}$. The target genes TH01, TPOX and D7S820 have repetitive sequences rich in TCAT, GAAT and GATA, respectively. Mouse pepsin may have a restriction enzymatic effect on these sequences, thus resulting in DNA degradation.

In qPCR method, when the Ct value is $>35$, the target gene is considered absent. In Table 4, from the amplification curve, the $\mathrm{Ct}$ value of the mouse gastric contents at 40 min was approximately $26(<35)$. The Ct values of the four target genes in the upper part of the small intestine of the mice at 40 min were all less than 35 , thus indicating that the four target genes were present in very low amounts; in the lower part of the mouse small intestine at $40 \mathrm{~min}$, only the GAPDH gene had a Ct value less than 35 . These results indicated the presence of a small amount of GAPDH, whereas the $\mathrm{Ct}$ values of the other three target genes were $>35$, indicating the absence of the target genes. Similarly, the target genes were not detected in the DNA of the small intestine contents in mice at other times after gavage (Figure 10). These results were consistent with the PCR results, indicating that DNA was further degraded into small fragments $<77 \mathrm{bp}$ in the small intestine by digestive enzymes and intestinal microorganisms. The DNA in human white blood cells was more easily degraded digested by the gastric juices in mice when it entered the intestines.

The STR technique was used to amplify small fragments of DNA. The average peak area (38 alleles; 77$446 \mathrm{bp}$ ) of 21 gene loci amplified by STR provides a good representation of DNA degradation ${ }^{[9]}$. The capillary zone electrophoresis-laser induced fluorescence method can be used to determine the DNA concentrations in serum and plasma, and is as accurate and sensitive as the widely used real-time PCR method $^{[31,32]}$.

The results obtained from plotting the average peak area and gavage time were consistent with the results of qPCR (Figure 11A). According to the natural logarithm of the average peak area versus the digestion time, the half-life of DNA degradation in the mouse stomach was $63.13 \mathrm{~min}$. This result was consistent with the half-life of DNA degradation calculated by qPCR method. After food enters the 
stomach, through mechanical digestion and chemical digestion ${ }^{[33]}$, part of the food bolus enters the intestines in the form of chyme. Our results showed that the rate of cellular DNA degradation in the mouse stomach was slow. STR map analysis of DNA in the small intestine in mice revealed that as the chyme advances in the small intestine, the number of human DNA alleles decreased (Table 5). qPCR and STR both clearly showed that human genomic DNA was markedly more degraded in the mouse intestine than the mouse stomach, whereas human target genes were degraded gradually in the mouse intestine with chyme advancement. Gene degradation times were also predicted through the STR method (Figure 11B).

$\mathrm{Liu}^{[19]}$ et al. reported that nucleic acids are digested in the stomach in blackhead fish and banded grouper, whereas the digestion of nucleic acids by bovine gastric enzymes was not observed. Different animals have varying ability to digest nucleic acids with pepsin. According to the experimental results of the current study, the mouse pepsin can be assumed to have a digestive effect toward human genomic DNA, thus, providing a potential reference for future experiments.

In recent years, no detailed research has performed a quantitative analysis of the degradation of DNA in the digestive tract in mice. Our findings should contribute to future food and drug research, and risk assessment of genetically modified foods.

\section{Conclusions And Recommendations}

The degradation of exogenous DNA was higher in mouse stomach during first two hours while almost complete degradation was noted in the small intestine of mice within $40 \mathrm{~min}$.

We observed the digestive kinetics in mice in vivo, and this information may be valuable in future experimental studies. However, because this experiment was based on observation of the mouse gastrointestinal tract after sacrifice, the time intervals were all integers; to refine the findings, further research and improvement are needed.

\section{6.declarations}

No conflict of interest exits in the submission of this manuscript, and manuscript is approved by all authors for publication. I would like to declare on behalf of my co-authors that the work described was original research that has not been published previously, and not under consideration for publication elsewhere, in whole or in part.

\section{References}

1. Vieira, B. R. C., Carvalho, E. F. \& Silva, D. A. Analysis of human DNA present in the digestive tract of Aedes aegypti mosquitoes for possible forensic application[J].Forensic Science International: Genetics Supplement Series,2017,6. 
2. Maturin, L. \& Sr Curtiss R 3rd. Degradation of DNA by nucleases in intestinal tract of rats., 196 (4286), 216-218 (1977).

3. McAllan, A. B. The fate of nucleic acids in ruminants. Proc Nutr Soc, 41 (3), 309-317 (1982).

4. Wilcks, A., van Hoek, A. H., Joosten, R. G., Jacobsen, B. B. \& Aarts, H. J. Persistence of DNA studied in different ex vivo and in vivo rat models simulating the human gut situation. Food Chem Toxicol, 42 (3), 493-502 (2004).

5. Loretz, B., Föger, F., Werle, M. \& Bernkop-Schnürch, A. Oral gene delivery: Strategies to improve stability of pDNA towards intestinal digestion. J Drug Target, 14 (5), 311-319 (2006).

6. Forsman, A., Ushameckis, D., Bindra, A., Yun, Z. \& Blomberg, J. Uptake of amplifiable fragments of retrotransposon DNA from the human alimentary tract. Mol Genet Genomics, 270 (4), 362-368 (2003).

7. Tony, M. A. et al. Safety assessment of Bt 176 maize in broiler nutrition: degradation of maize-DNA and its metabolic fate. Arch Tierernahr, 57 (4), 235-252 (2003).

8. Rossi, F. et al. Effect of Bt corn on broiler growth performance and fate of feed-derived DNA in the digestive tract. Poult Sci, 84 (7), 1022-1030 (2005).

9. Sharma, R. et al. Detection of transgenic and endogenous plant DNA in digesta and tissues of sheep and pigs fed Roundup Ready canola meal. J Agric Food Chem, 54 (5), 1699-1709 (2006).

10. Tudisco, R., Cutrignelli, M. I., Calabrò, S. \& Guglielmelli, A. Investigation on genetically modified soybean (Round Up Ready) in goat nutrition: DNA detection in suckling kids[J] (Italian Journal of Animal Science, 2010).

11. Tudisco, R. et al. Fate of transgenic DNA and evaluation of metabolic effects in goats fed genetically modified soybean and in their off springs. Animal, 4 (10), 1662-1671 (2010).

12. Walsh, M. C. et al. Fate of transgenic DNA from orally administered Bt MON810 maize and effects on immune response and growth in pigs. PLoS One, 6 (11), e27177 (2011).

13. Sattarzadeh, A., Rahnama, H. \& Nikmard, M. Detection of genetically modified food in digesta and organs of rats fed transgenic potato[J].JOURNAL OF ANIMAL AND FEED SCIENCES.2018,Vol.27(No.2):163-172.

14. Trojan, V. et al. Detection of DNA fragments from wheat in blood of animals. J. Verbr. Lebensm, 11, 259-264 (2016).

15. Nawaz, M. A. et al. Addressing concerns over the fate of DNA derived from genetically modified food in the human body: A review. Food Chem Toxicol, 124, 423-430 (2019).

16. Carver, J. D. \& Walker, W. A. The role of nucleotides in human nutrition. J Nutr Biochem, 6, 58-72 (1995).

17. Liu, Y. et al. Digestion of Nucleic Acids Starts in the Stomach. Sci Rep, 5, 11936 Published 2015 Jul 14. (2015).

18. Zhang, Y. et al. The effects of food components on the digestion of DNA by pepsin. Int J Food Sci Nutr, 67 (7), 797-805 (2016). 
19. Liu, Y. et al. Nucleic acids digestion by enzymes in the stomach of snakehead (Channa argus) and banded grouper (Epinephelus awoara). Fish Physiol Biochem, 43 (1), 127-136 (2017).

20. Holst-Jensen, A., Rønning, S. B., Løvseth, A. \& Berdal, K. G. PCR technology for screening and quantification of genetically modified organisms (GMOs). Anal Bioanal Chem, 375 (8), 985-993 (2003).

21. Holst-Jensen, A. Testing for genetically modified organisms (GMOs): Past, present and future perspectives. Biotechnol Adv, 27 (6), 1071-1082 (2009).

22. Wang, Y. Chen Mei,Xiao Nan,Liu Hui. Evaluation and comparison of in vitro degradation kinetics of DNA in serum, urine and saliva: A qualitative study[J]. Gene,2016,590(1).

23. Francis, J. et al. Comparisons betweenthe effects of $5-\mathrm{TH}$ and dl-fenfluramine on food intake and gastric emptying in the rat. Pharmacol Biochem Behav, 50 (4), 581-585 (1995).

24. Hammond, H. A., Jin, L., Zhong, Y., Caskey, C. T. \& Chakraborty, R. Evaluation of 13 short tandem repeat loci for use in personal identification applications. Am J Hum Genet, 55 (1), 175-189 (1994).

25. Lau, T. W. et al. Fetal DNA clearance from maternal plasma is impaired in preeclampsia. Clin Chem, 48 (12), 2141-2146 (2002).

26. O'Driscoll, C. M., Bernkop-Schnürch, A., Friedl, J. D., Préat, V. \& Jannin, V. Oral delivery of non-viral nucleic acid-based therapeutics - do we have the guts for this? Eur J Pharm Sci, 133, 190-204 (2019).

27. Lim, C. H., Choi, M. G., Park, H., Baeg, M. K. \& Park, J. M. Effect of DA-9701 on gastric emptying in a mouse model: assessment by ${ }^{13} \mathrm{C}$-octanoic acid breath test. World J Gastroenterol, 19 (27), 43804385 (2013).

28. Miraglia, M. et al. Detection and traceability of genetically modified organisms in the food production chain. Food Chem Toxicol, 42 (7), 1157-1180 (2004).

29. Nguyen, T. L., Vieira-Silva, S., Liston, A. \& Raes, J. How informative is the mouse for human gut microbiota research? Dis Model Mech, 8 (1), 1-16 https://doi.org/10.1242/dmm.017400 (2015).

30. Wiedemann, S., Lutz, B., Kurtz, H., Schwarz, F. J. \& Albrecht, C. In situ studies on the time-dependent degradation of recombinant corn DNA and protein in the bovine rumen. J Anim Sci, 84 (1), 135-144 (2006).

31. Zhang, P., Ren, J. \& Shen, Z. A new quantitative method for circulating DNA level in human serum by capillary zone electrophoresis with laser-induced fluorescence detection., 25 (12), 1823-1828 (2004).

32. Sang, F. \& Ren, J. Comparisons between capillary zone electrophoresis and real-time PCR for quantification of circulating DNA levels in human sera. J Chromatogr B Analyt Technol Biomed Life Sci, 838 (2), 122-128 (2006).

33. Heda, R., Toro, F. \& Tombazzi, C. R.. Physiology, Pepsin. In: StatPearls. Treasure Island (FL):StatPearls Publishing; 2020.

\section{Figures}




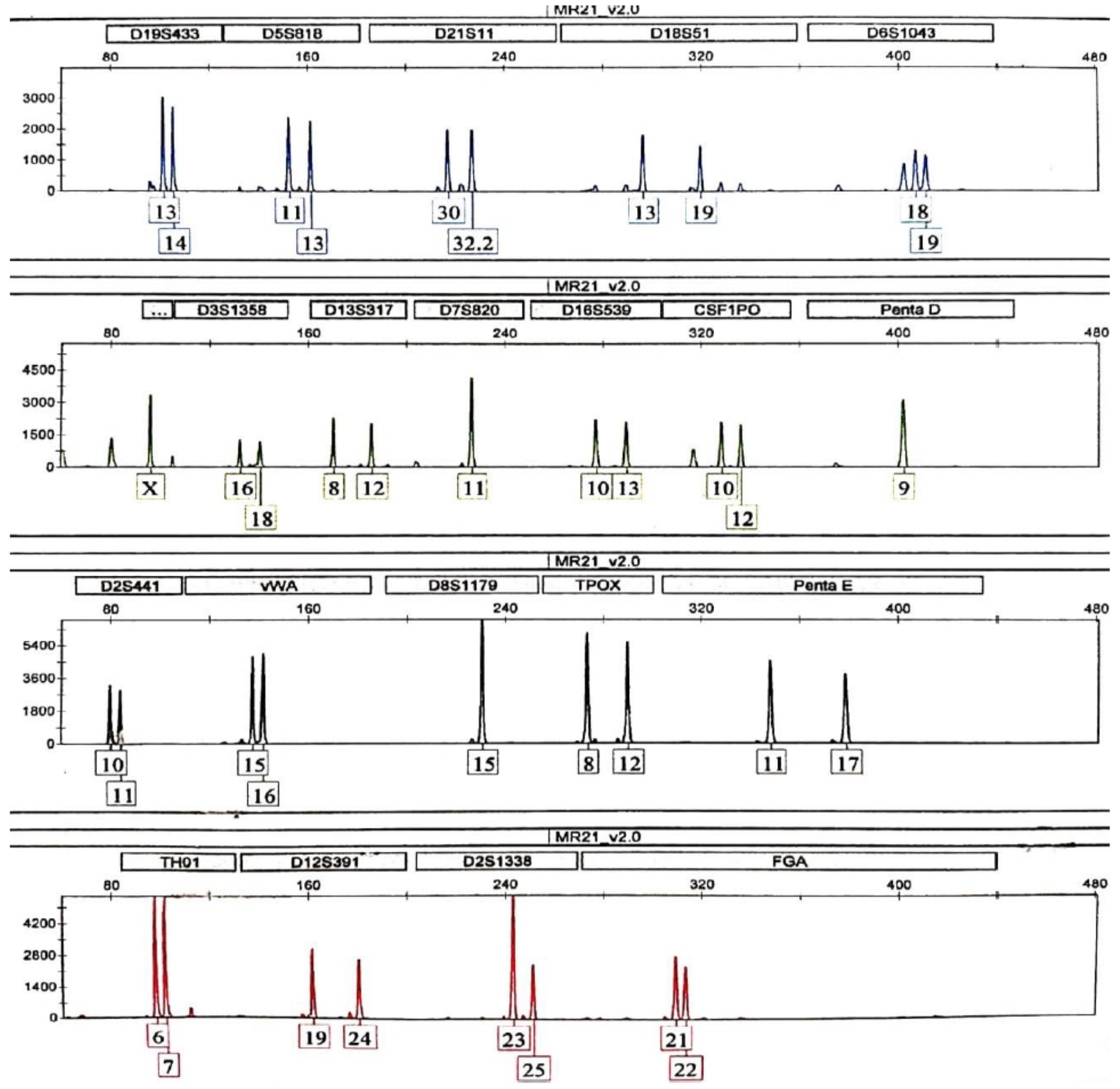

Figure 1

STR map of a sample. 


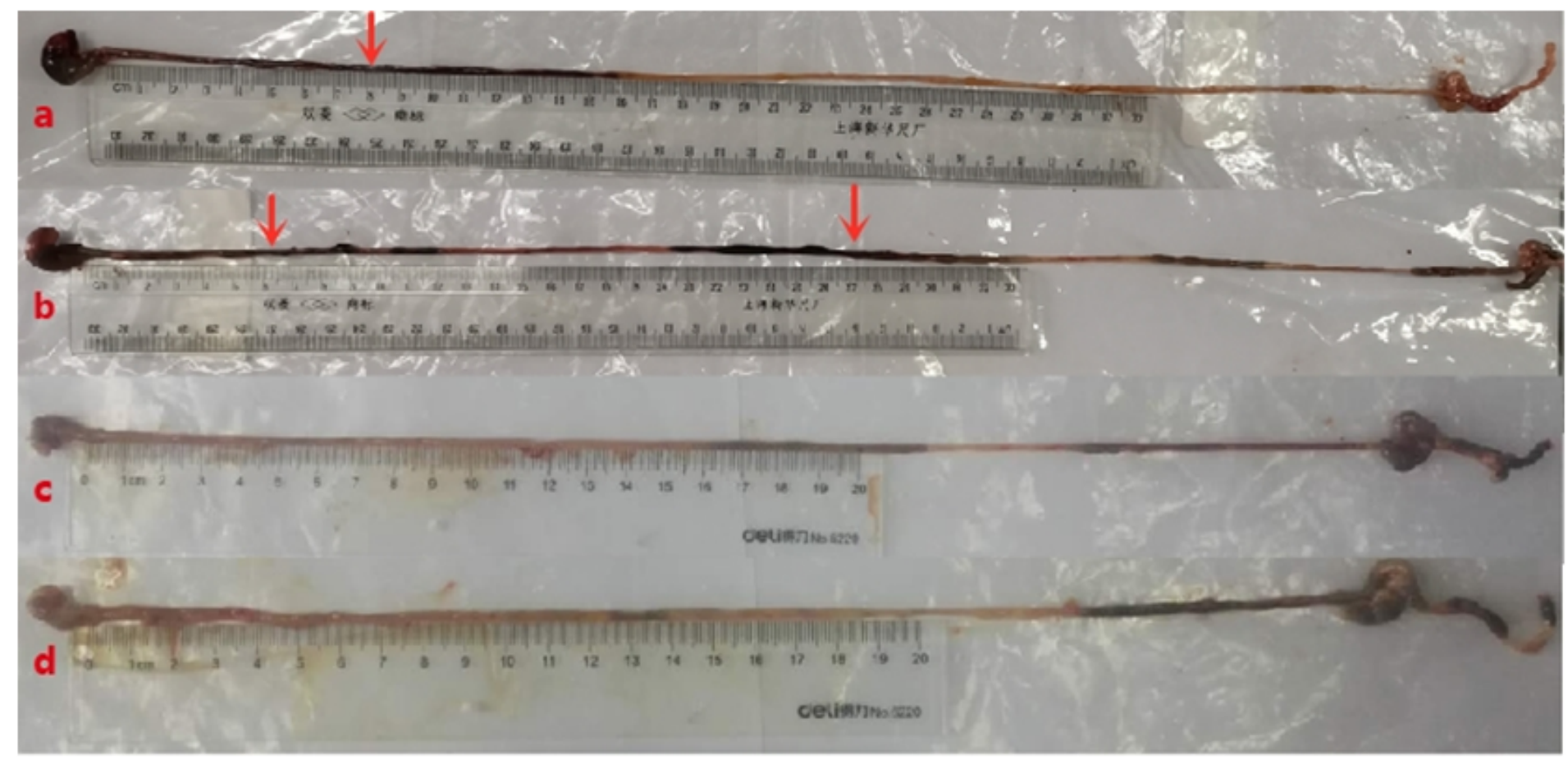

\section{Figure 2}

From left to right, the image shows the mouse stomach, small intestine and cecum; black represents the location of the nutritional semi-solid paste. a: GIT in mice 10 min after gavage. b: GIT in mice 20 min after gavage, c: GIT in mice 360 min after gavage. d: GIT in mice 420 min after gavage.

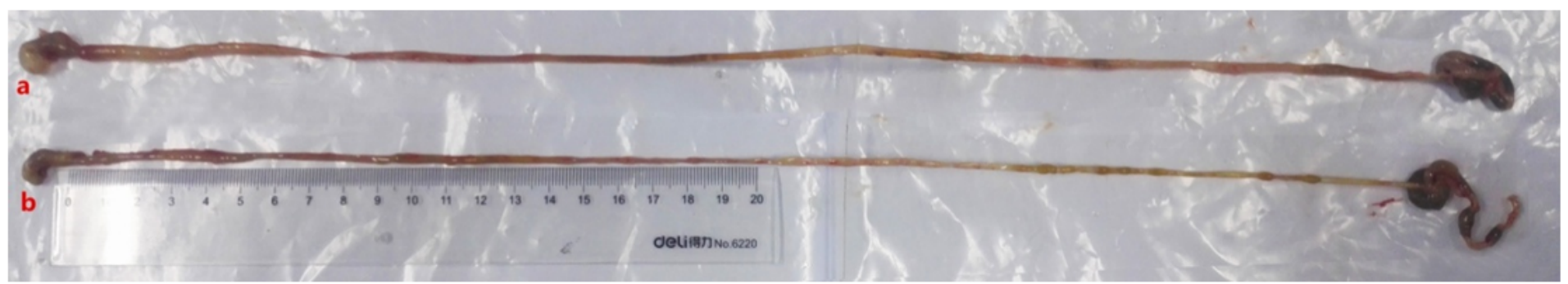

\section{Figure 3}

$a$ and $b$ are GIT images from mice 540 min and 570 min after gavage. Whole nutritional semi-solid paste in the stomach and small intestine entered the cecum. 


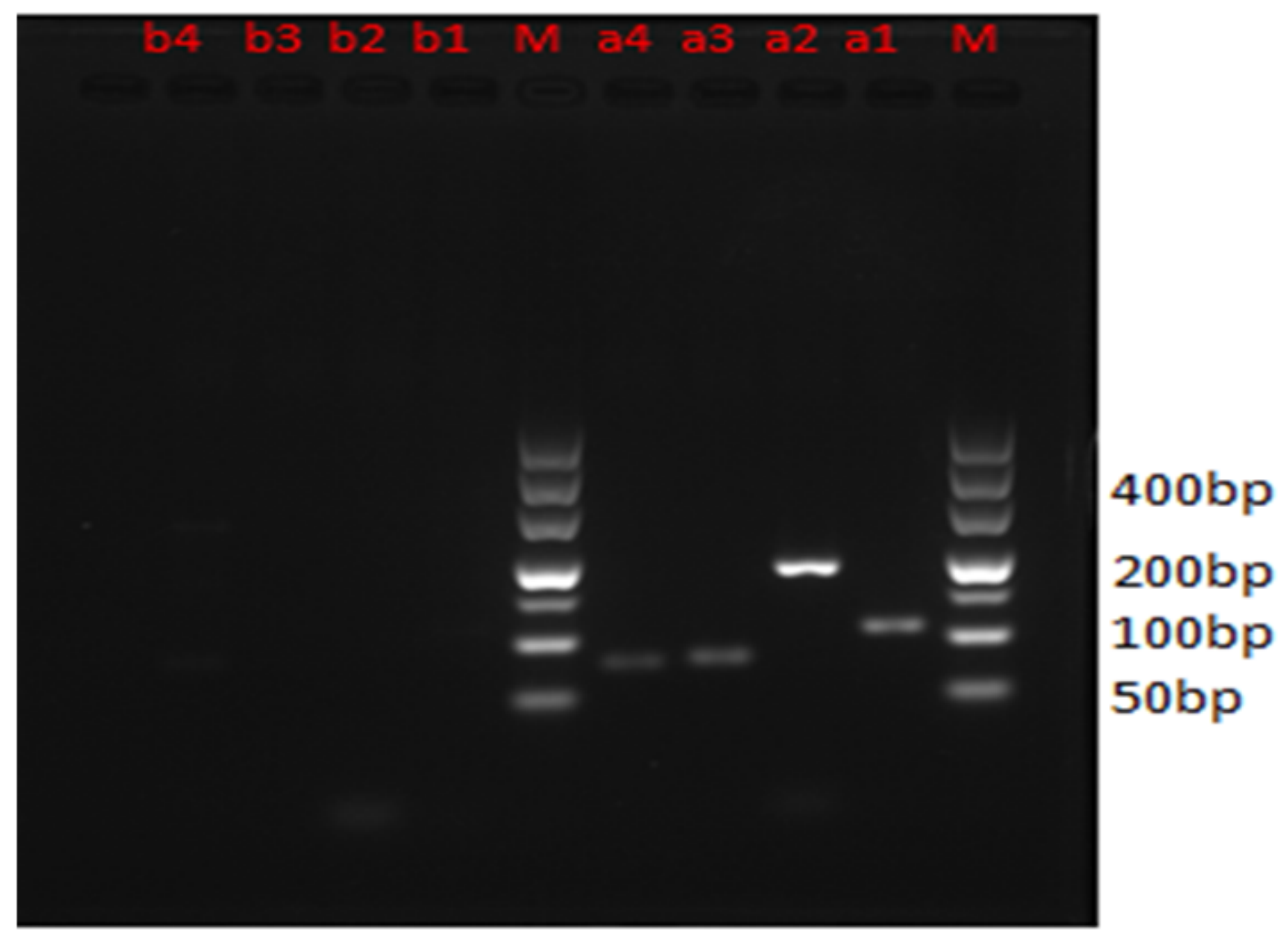

Figure 4

Lane M : 500 bp DNA marker, lanes a1-a4 : human blood DNA (template DNA used to amplify the target genes GAPDH, TH01, TPOX and D7S820), with clear bands. Lanes b1-b4: mouse liver DNA (template used to amplify the target genes GAPDH, TH01, TPOX and D7S820), with no bands. 


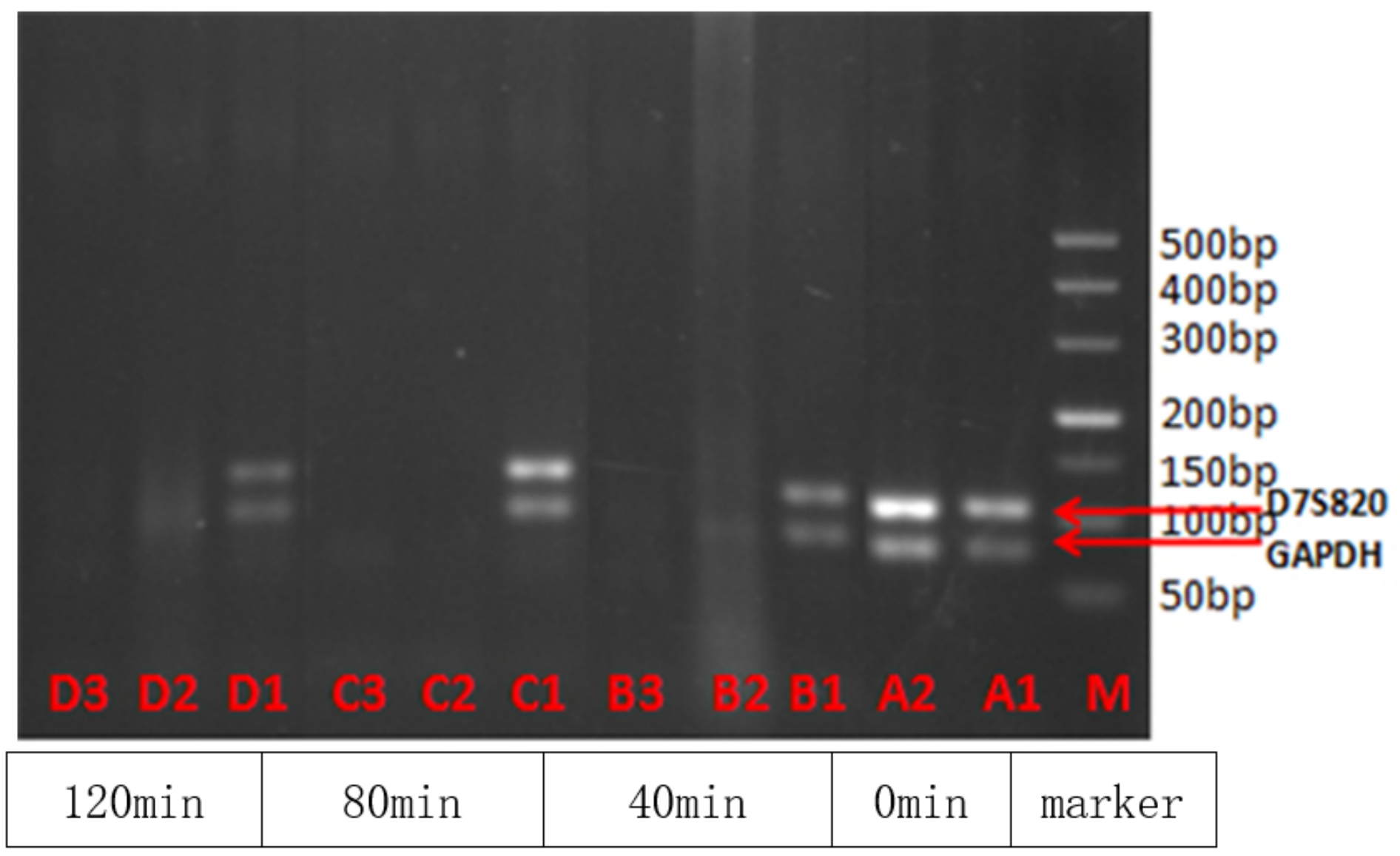

Figure 5

Lane M: 500 bp DNA marker. Lanes A1 and A2: pre-gavage (0 min). Lanes B1-B3, C1-C3, D1-D3: postgavage times of 40, 80, 120 min, respectively. Lanes B1, C1 and D1: stomach contents, with GAPDH and D7S820 bands. Lanes B2, B3, C2, C3, D2 and D3: small intestine contents, with no DNA bands. 


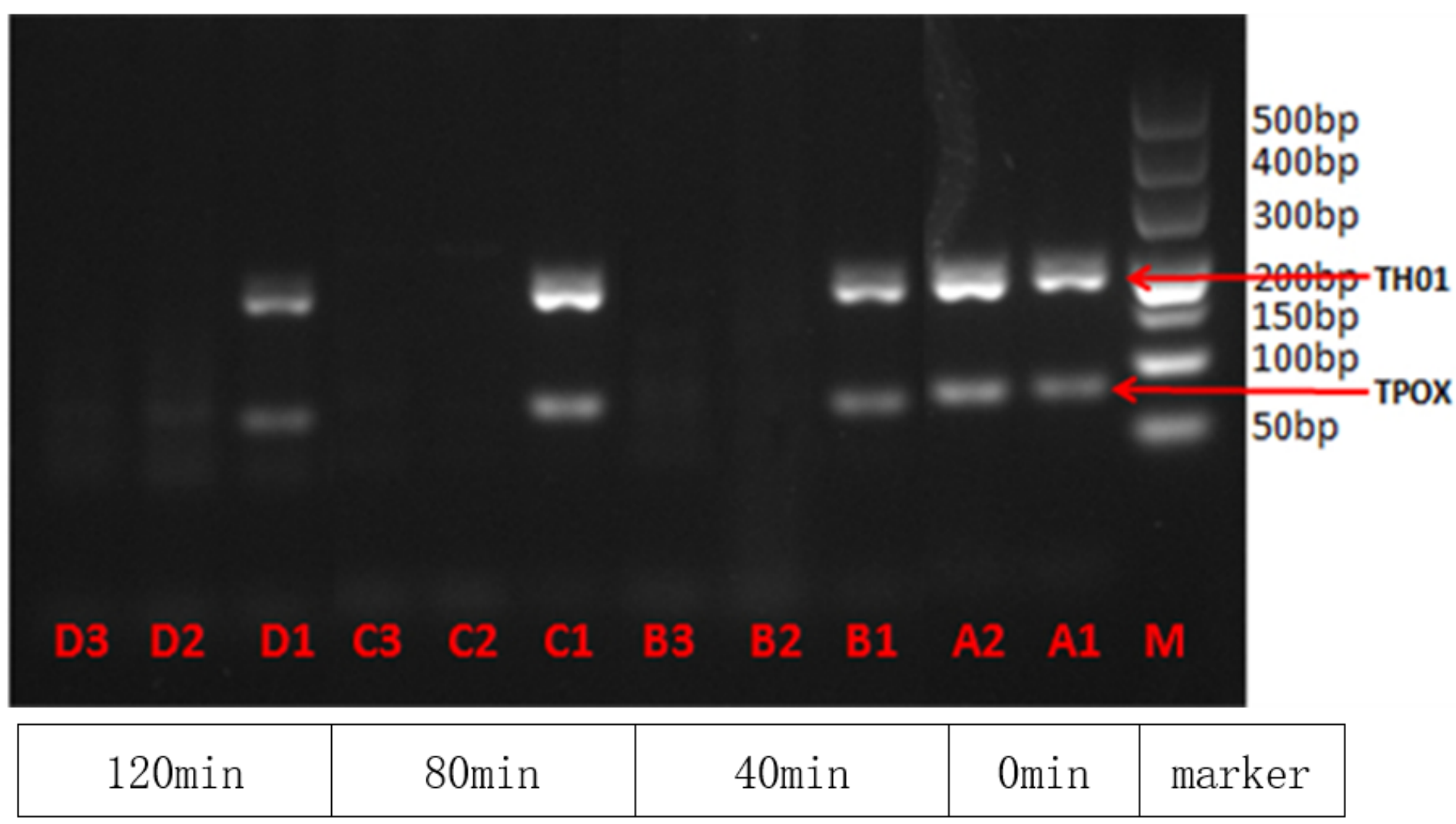

Figure 6

Amplification of the TH01 and TPOX genes. Lane M: DNA marker. Lanes A1 and A2: pre-gavage. Lanes B1-B3, C1-C3, D1-D3: post-gavage times of 40, 80, 120 min, respectively. Lanes B1, C1 and D1: stomach content DNA bands. Lanes B2, B3, C2, C3, D2 and D3: small intestine chyme, with no DNA bands. 


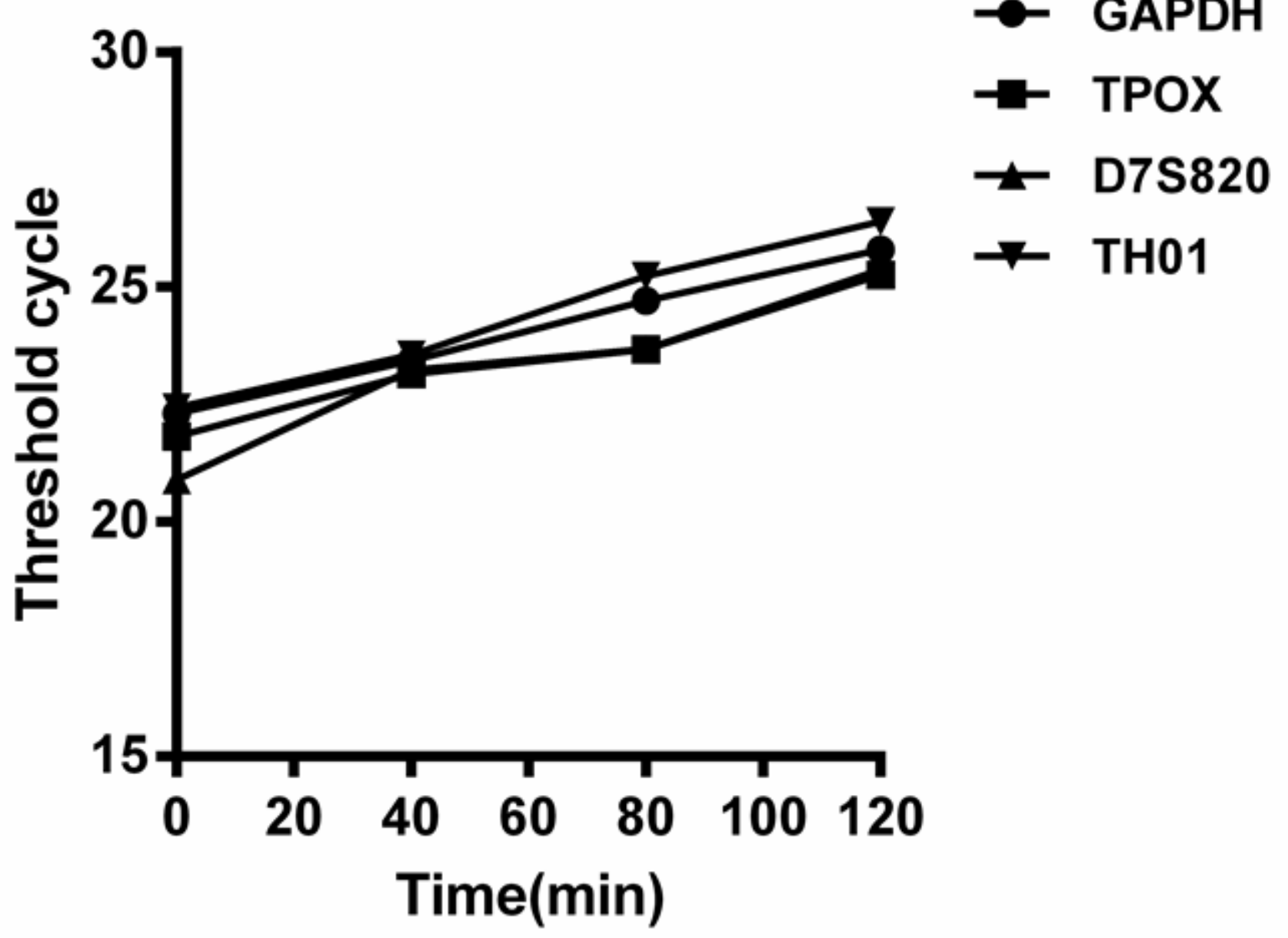

Figure 7

Ct values of four target genes at various times. 


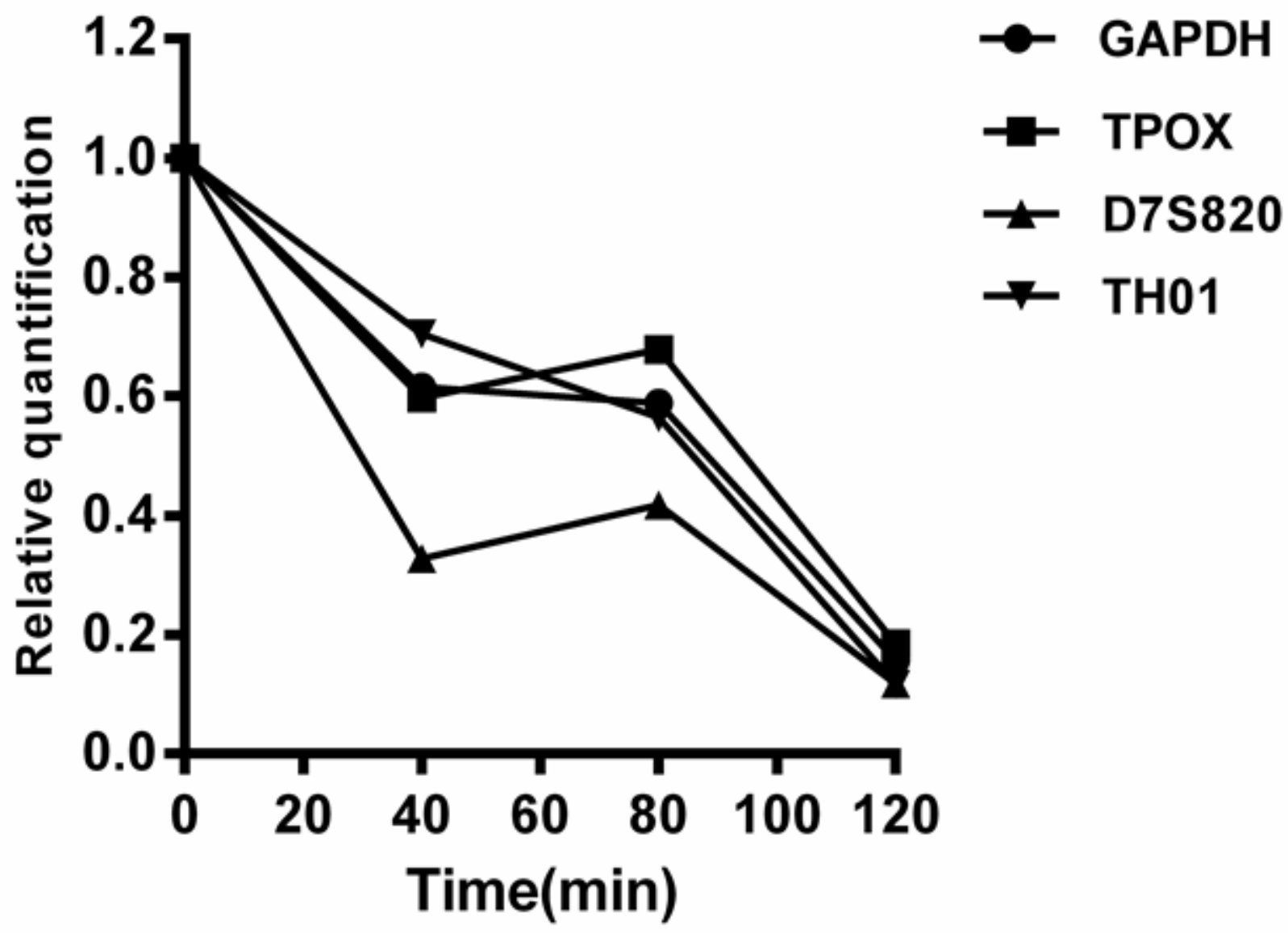

Figure 8

Relative Ct values of four targeted genes at different digestion time. 


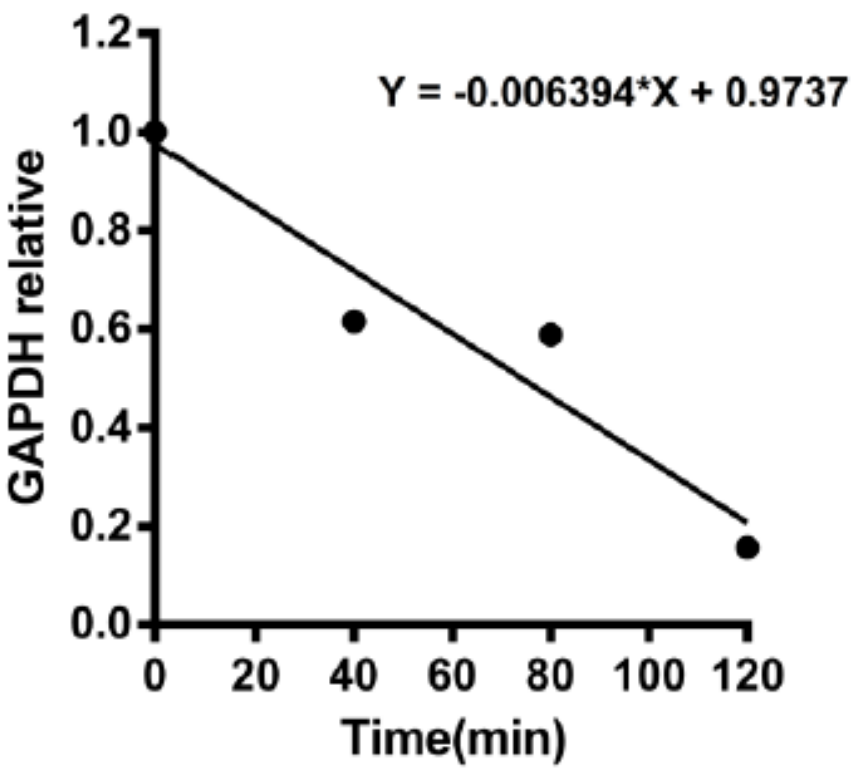

A

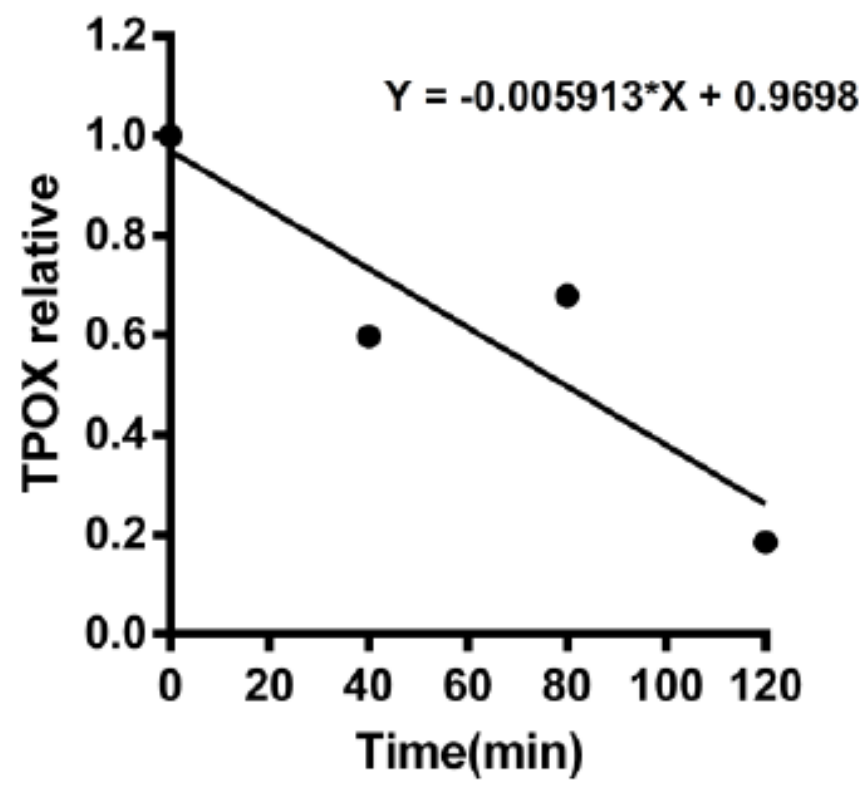

$\mathrm{C}$

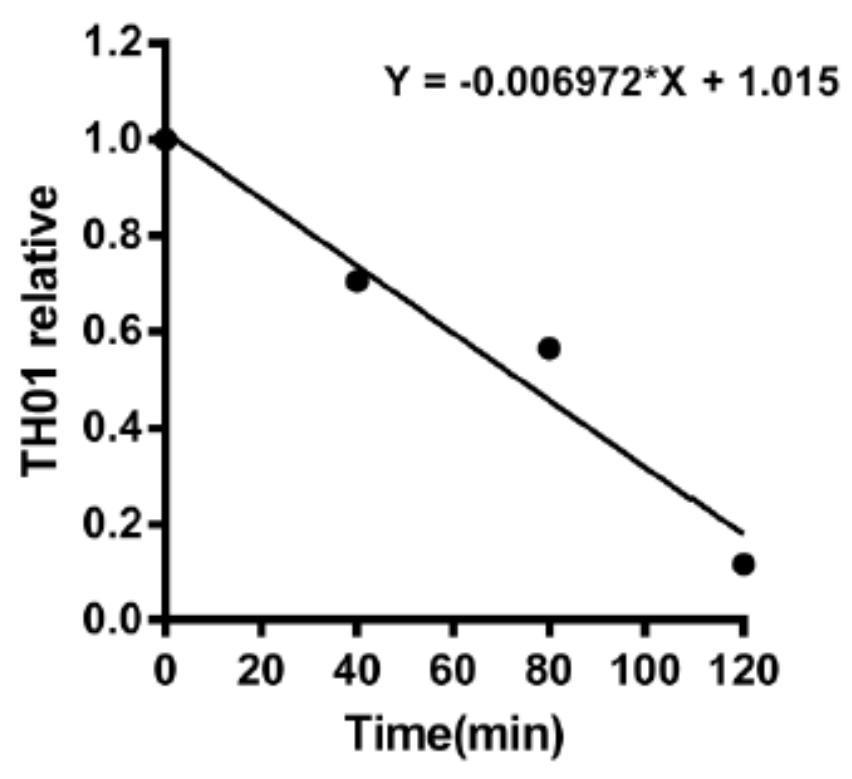

B

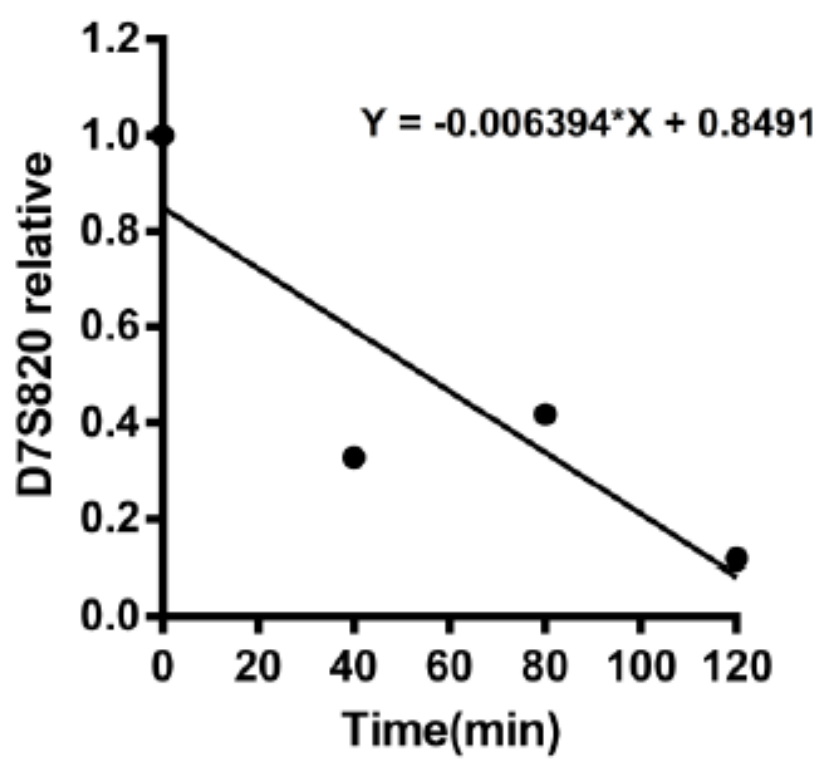

$\mathrm{D}$

Figure 9

$A, B, C, D$ are the DNA relative quantitative linear relationship of the four target genes with digestion time 


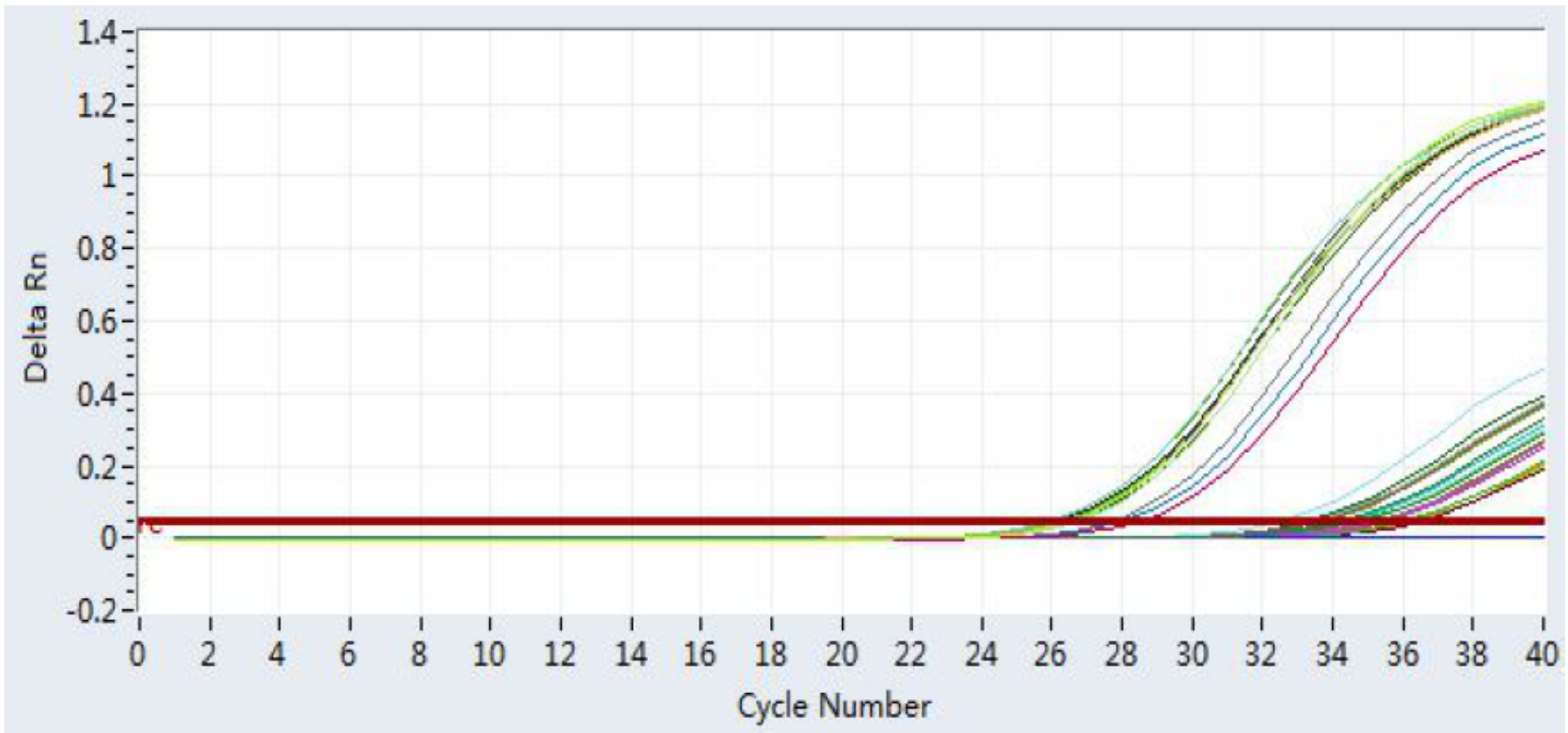

Figure 10

Amplification curves of four target genes from different parts of the GIT in mice 40 min after gavage.

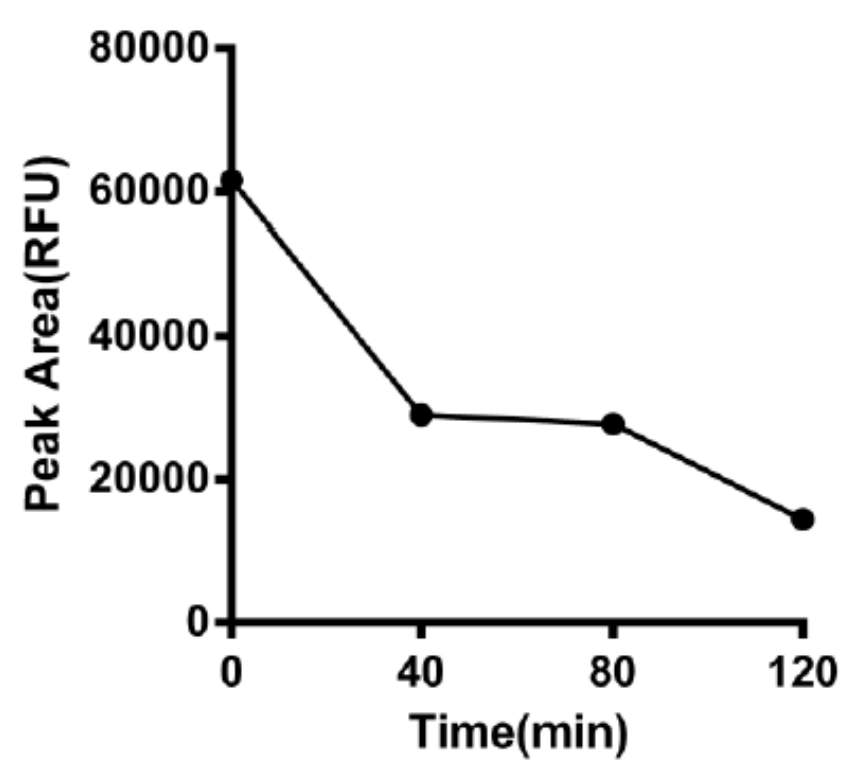

A

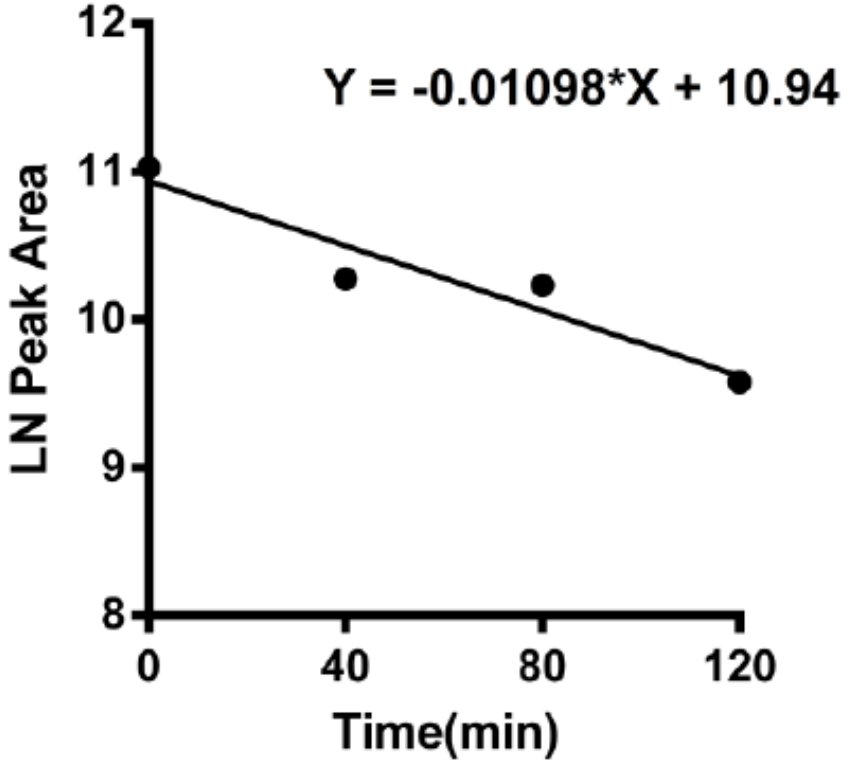

B

\section{Figure 11}

$A:$ average peak area of the stomach contents in mice at different digestion times. B: linear regression analysis of the natural logarithm of the average peak area versus digestion time(The half-life is 63.13 
minutes).

\section{Supplementary Files}

This is a list of supplementary files associated with this preprint. Click to download.

- asupplementaryfile.docx 